\title{
Different Modes of Competition? Early Modern Universities and Their Rivalries
}

\author{
Gerhard Wiesenfeldt
}

\begin{abstract}
Unterschiedliche Formen von Konkurrenz? Frühneuzeitliche Universitäten und ihre Rivalitäten
Ausgehend von den Konkurrenzbegriffen Niklas Luhmanns und Georg Simmels untersucht der Artikel, inwieweit sich Konkurrenzverhältnisse an frühneuzeitlichen Universitäten in den Begriffen von Konkurrenzbedingungen moderner Ökonomie interpretieren lassen. Dieses wird anhand von Gelehrtenstreiten, dem Disputationswesen sowie Konflikten über professorale Privilegien und Universitätsgründungen diskutiert. Die zentrale These lautet, dass ökonomische Bedingungen sehr wohl eine wesentliche Rolle für Konkurrenzverhältnisse spielten, diese aber eben dem feudalistischen Wirtschaftssystem entsprachen und auf Erlangung bzw. Wahrung von Pfründen und Privilegien ausgerichtet waren. Ein moderner Konkurrenzbegriff ist demnach nur sehr begrenzt anwendbar.
\end{abstract}

Schlüsse/wörter: Universitäten, Frühe Neuzeit, Konkurrenz, Gelehrtenstreit, akademische Privilegien

Keywords: Universities, early modern period, competition, scholarly dispute, academic privileges

Competition, it seems, has become a central element of the life-world in twentyfirst century universities. National or international competitive grant programs or university rankings, performance driven funding models and scientometric research evaluations have implemented a logic of competition based on measurable quantities (Hicks 2012), a logic that is subsequently applied to individual academics leading to more precarious career patterns (Nadolny and Ryan 2015). University governors and academics alike frequently stress the change the increased competition has brought to their institution and their respective personal roles, even though the assessments of the costs and benefits of this change often diverge fundamentally (Hazelkorn 2015; Halffmann and Radder 2015). In these assessments competition among and within universities is often related to a changing economic structure of universities either as private enterprises or as corporations behaving like those. Competition-or more specifically, this mode of competition-thus seems to be a rather recent phenomenon in the academic world, even though 
comparisons between early and late modern universities sometime offer intriguing parallels (Stollberg-Rillinger 2011). This article will study whether and how early modern universities competed among each other or with other institutions, and how competition appeared within these institutions. It will focus on potential points of competition in order to understand how these affairs were perceived at these institutions, and how an understanding of competition and rivalry can be linked to the economic structures of early modern universities.

\section{Rivalry, Conflict or Economic Competition?}

Current debates on competition within and between universities are based on economic models, which broadly understand competition as the struggle between different parties for a scarce resource (Hunt 2000), regardless if the resource consists in material goods, money or symbolic capital (Bourdieu 2011). In this perspective, competition comprises the work that is undertaken to gain the resource, irrespective of whether the competition follows-however formalized-rules ${ }^{1}$ or whether the resource actually exists beyond the subjective views of the participants. Yet, this notion of competition does assume that the competitors regard each other as such and adjust their actions accordingly; competition thus assumes a form of instrumental rationality. Niklas Luhmann (1988: 101-110) has pointed out that economic competition is not in itself a social system but a structuring principle of the environment that reduces the complexity for every market participant. Competition-as well as cooperation or exchange with other participants-allows for differentiation of the economic system. Yet unlike the latter two principles competition produces social orientation without direct social interaction and thus avoids direct conflict between competitors, at least in principle. Thus an important aspect of the notion of modern economic competition is its abstract nature in comparison to direct political or intellectual conflict. Whether similarly abstract forms of competition without direct social interaction existed within or among early modern universities is an important issue for the topic of this article. In contrast to Luhmann, Georg Simmel understands economic competition as a specific form of conflict, which is related to other forms of competition, such as rivalry in love, within families and even within and among religious groups (Simmel 1955: 57-85). While he points to the ubiquity of competition in modern life as "the fight of all against all" and "the fight of all for all" (ibid.: 62), he focuses on the consequences this state has on the configuration of the social groups in which competition takes place. In many cases, for instance in families or religious groups, either the group interests or general principles necessitate structures that prohibit and limit competition. In this context Simmel discusses the early modern guild system 
as one that excludes the competitive form of production (ibid.: 74-76), while his analysis of modern economic competition as one where competitors remain, at least in principle, socially distinct from each other, sometimes even to the point where legal restrictions disallow collaboration to avoid cartelization (ibid.: 77).

A direct application of the modern economic concept of competition to early modern universities seems to be burdened with a few obstacles. It is not clear how the assumption of guiding principles based on instrumental rationality can avoid contradictions when applied to institutions that are as deeply embedded in the pre-modern representative public sphere as has been the case for universities (Habermas 1971: 58-68). At the very least such an approach runs the risk of being ahistorical. A perspective on the economic structure of early modern universities endorses such a caveat. They were organized according to feudalistic principles, relying on sinecures for their income $^{2}$ and often very strong in resisting mercantilist or cameralistic reforms (Kublik 2009). Internally, professorships tended to be treated as sinecures as well, inclined to be passed on according to seniority or family relationships and less according to merit (Moraw 1982). Hence, academic degrees were frequently rather formal acknowledgments of the affiliation to the scholarly ranks than certificates of intellectual achievement (Vermij 1991; Frijhoff 1996b: 370-377). Following a Luhmannian perspective, Stichweh (1991) has looked at the way early modern universities have transformed themselves internally and adapted to a changing environment presented by newly emerging societal and governmental demands. Again, the central element of the early modern university remains its corporate structure that emphasized privileges as key units of their feudal economy, thus inducing a strong resistive element against external demands for change (ibid.: 291-306; 341-350; Dölemeyer and Mohnhaupt 1997). It is hard to imagine any sizeable space for economic competition in this framework, either within or between universities. In this aspect, universities do not appear to have been fundamentally different from their environment. Following Simmel's analysis, Stollberg-Rilinger (2014) has argued that the rejection of economic competition was a crucial element of the early modern social status order. "Active competition for a higher social status was by no means a social norm, but entirely to the contrary a violation of the norm". ${ }^{3}$

\section{Scholarly Rivalries: Disputations as Competition?}

Then again, throughout history universities have been famous for a particular form of rivalry, that is, the scholarly dispute, which does seem to involve a high degree of competition among scholars. Yet, it is not immediately evident that 
this form of competition follows the modern economic model. There may be cases when this does apply, for example, in priority disputes (Merton 1957). While it can be argued that priority disputes are exceptional as they are necessary side-effects of otherwise important social norms, one can go further in interpreting scholarly disputes as competitions among the scarce resource of truth-or at least the slightly less scarce resource of interpretive authority. Yet, in other respects the scholarly dispute is characteristically different from economic competition. In a proper scholarly dispute it is well possible that both adversaries benefit in valor and status from the debate. Even if the scholarly dispute is a form of competition, it differs from modern economic competition not just by relying on direct social interaction, but also by each competitor's relying on the existence of the adversaries. For a dispute scholars do require the existence of other scholars, thus they are in the same structural situation as knights in a medieval tournament or modern football players (Crouch 2005). While the need for multiple competitors also applies for economic competition, it does not apply to the competitors in this competition, who-at least in principle-can also conduct their business as monopolists. While it might be possible to argue that scholars can in principle function as monopolists in their field, it is important to note that early modern scholars did not shared this view. Quite the contrary: early modern literature on scholarly disputes emphasized the dialogical nature of the dispute as an essential and productive element (Gierl 1997: 125-168).

The established ritual to perform the scholarly dispute was the disputation, which underwent a few major transformations between the sixteenth and the eighteenth century (Chang 2004; Gindhart and Kundert 2010). A disputation could fulfil two different functions: it could serve as central instance in a student's graduation towards a doctorate (Marti 2007; Füssel 2006: 149-187) or as an exercise for students to enhance their academic skills (Wiesenfeldt forthcoming). Whereas the former tended to be a formalistic affair designed to avoid any controversy that might endanger the student's success, the latter became a central point for debate, if not outright academic in-fighting, during the early modern era.

While they were frequently criticized as a medium that was either unsuitable in principle for academic debate or at least spoiled through frequent misuse (Bacon 2000: 58-59; Descartes 1998: 56), disputations showed a remarkable persistence in academic life. Contrary to the views of Bacon and Descartes many scholars after 1650 appreciated the values of disputations and focused in particular on the right method of disputations, which they related directly to the broader debate on scholarly disputes. Compared to earlier textbooks on disputational logic that had specifically addressed students taking on the role as respondent or opponent in a disputation, Andreas Prückner's Libellus de Artificio Disputandi (1656), Johann Paul Felwinger's Brevis Commentatio de Disputatione (1659), and Johann Christian Hebenstreit's De 
praeside disputationis ejusque officio (1717) were more elaborate in setting specific rules for the praesides of disputation (cf. Felipe 1991: 184-192). These rules were regarded as necessary to avoid wasting time and bickering as well as to sharpen judgment and lead to a better understanding of disputation (Prückner 1656: 164f.). Such comments can be read as a reaction to developments that had led to the changed character of disputations. Whereas during the Reformation period disputations between scholars had played a major role (Moeller 2011), disputation in the seventeenth century became an academic exercise mostly performed by students. That does not imply that disputations lost their significance for scholarly disputes, but now academics used them to dispute about-and usually against-absent scholars. ${ }^{4}$ As the others scholars frequently retaliated with the same technique, this form of competition can be interpreted within the economic model. Yet, this was exactly the kind of controversy that both opponents and reformers of disputations rejected. Representatives of the latter group stressed the dialogical character of disputations as this was well suited for an appropriate evaluation of the arguments under debate (Heereboord 1648; cf. Albrecht 1994: 278287).

In the decades following Heereboord's extensive appraisal of the disputation as the ideal instance for debating truth in philosophy, disputations increasingly turned from an instance in which truth was established into one in which the method of establishing the truth was learned and exercised. While a good disputation still consisted of a debate in which the respondent could overcome all objections raised by the opponents, the proper method of refuting objections became increasingly important (Thomasius 1670). The main goal of the disputation thus became the learning of practices that subsequently were to be practiced in a scholarly dispute. Disputation and scholarly dispute thus parted ways during the seventeenth century.

A major difference between the scholarly dispute and the disputation (and likewise medieval tournaments and modern football games) consists in the former's potentially perennial duration, notwithstanding the inevitable lethal end of the participants. Hence it was not always beneficial for a party in a scholarly dispute when their opponents gave in, as the persistence of the dispute tended to enhance the prestige of the cause and subsequently that of the participating parties. The controversy between Christian Thomasius and Christian Wolff on one side and the Halle Pietists surrounding August Hermann Francke on the other became the crucial moment of the early German enlightenment, as the two contrary positions became the central reference points for the philosophical and theological discourse at German universities through the prominence of their dispute (Gierl 1997: 418-486).

William Clark (2006) has characterized the early modern German professor-at least during the latter part of that period-as a persona that has an inherent drive towards 'academic charisma,' showing exceptional qualities of 
intellect and power. While the term 'charisma' might characterize the professorial position close to a revelatory preacher (Corcoran 2013: 123-125), the disputes performed through the institution of the disputation prima facie seem to fit well with Clark's argument. From this perspective it may be puzzling that he sidelines disputations in his overall story, as according to Clark disputations declined in the early modern period and their "decadence [...] could not be remedied" (Clark 2006: 99). While this claim is difficult to sustain in the light of recent scholarship on the topic (Marti 1999; Chang 2004), Clark's difficulties to relate conflicts about disputations to the functions of academic charisma point to a curious way disputations, even between deeply antagonistic academics, were not primarily about winning the contest of ideas. Instead, they related strongly to the status and honor of the participants, which should not be compromised. As Füssel (2006: 188-332) has shown in great detail, conflicts in early modern universities were primarily interpreted as conflicts about status and thus as unwanted debates on issues that should not have given rise to offence. Therefore disputations necessarily had a dialectic nature with respect to their competitive function-controversy was both inevitable and to be avoided.

\section{Rivaling Academics and Rivaling Universities}

Scholarly disputes were not the only potential forms of competition at early modern universities and among early modern scholars. At individual level these rivalries pertained to basic economic matters, such as income through honorariums and student fees. Still, these rivalries were addressed in terms of the privileges granted to academic teachers, which were carefully guarded. The public announcement of lectures remained limited to select groups of teachers, ordinary professors at some universities such as Jena (Bauer 2008: 55), officially appointed teachers at others such as Leiden (Molhuysen 1913-1924: I, $\left.400^{*}\right){ }^{5}$ Often, the teaching of certain topics was reserved to a specific professorship at a university, guaranteeing the incumbent a certain income equivalent to a sinecure (Vandermeersch 1996: 213). A sizeable body of literature explained and justified the academic privileges and the differences between the ranks. ${ }^{6}$ Occasionally, however, the privileges and prerogatives of the professors were not sufficient to avoid direct competition among the academics of equal status, which could generate the need for formal regulations. So, after some apparent disagreement among their ranks, the Philosophical Faculty of Leiden University decided in 1675 to amend their faculty statutes by a minimum payment of 15 guilders for private lectures of professors and prohibited its members to charge less. ${ }^{7}$ Any economic competition within that group was to be avoided. It was not until the government bureaucracy started to gain an influence on the universities during the 
eighteenth century that internal competition over lectures emerged (Saada 2008: 43).

During the early modern period, however, there was an increasing economic strain on the university sector in general. The sixteenth century had seen a surge in new universities in consequence of the Reformation, the formation of the early modern state and the colonial expansion (Frijhoff 1996a: 70-74). Yet, from the late sixteenth century onwards the matriculation numbers across Europe declined slowly, but steadily until the late eighteenth century (Chartier: 1982). Given that universities were striving to increase their enrolments, a competition among them seems to have been inevitable. Apart from new universities a large number of illustrious schools and academic gymnasia catered for a clientele that the universities aimed to win as their own students. Universities responded to this situation by emphasizing their status and their privileges. The latter often pertained to claims about the political territory to which the university had been granted a privilege that would be threatened by institutions with similar status. Thus, when the city of Amsterdam decided to establish an illustrious school-the Amsterdam Athenaeum-the University of Leiden objected strongly to these plans and started legal proceedings before the provincial States of Holland (Frijhoff 1998). In its complaint, Leiden referred to its own foundation charters, which stipulated that "no other school [...] should be founded or erected in Holland or Zeeland" (Molhuysen 1913-1924: II, 216*). In its response, Amsterdam argued that the word 'school' needed to be understood differently, as a distinction between a university and an illustrious school had to be made. This would be common practice, as in many other countries a co-existence between universities and illustrious schools could be found, even in countries for which universities had a special privilege (ibid.: $225^{*}-228^{*}$ ). Such precedents included the provinces Holland and Zeeland, given that illustrious schools had been founded in Dordrecht and Middelburg in 1579 and 1592, respectively. ${ }^{8}$

It seems indeed a bit puzzling that Leiden University had accepted the school foundations in Dordrecht and Middelburg without any complaint, yet employed all political and legal means to thwart the plans of Amsterdam. It is possible that the university saw itself in a stronger position in 1631 than it had been in the first decades after its own foundation. However, a different aspect was probably more relevant for the resistance of Leiden. Amsterdam had appointed Caspar van Baerle and Gerrit Jan Vossius as foundation professors of the Athenaeum (van Miert 2009: 45-55). Both scholars had previously held professorships at Leiden. In particular, the appointment of Vossius had caused a lot of bad blood, as its circumstances were not entirely agreeable. Both Vossius and the city of Amsterdam had initially kept the appointment secret, and when the curators of Leiden University finally became aware of the plans and admonished him to do his duties, the historian responded by claiming that he had not accepted the offer in any way. Five months later, however, he asked 
to be relieved of his responsibilities at Leiden. By that time he had already moved to Amsterdam (including his family and his library), which of course had not gone unnoticed in Leiden. The university curators noted dryly that Vossius' letter was hardly a request to be dismissed, but a notification of unauthorized resignation (Molhuysen 1913-1924: 164). In short, these circumstances were not conducive to lightening political atmosphere. Leiden interpreted them as an indication that Amsterdam aimed to rival the established university and infringe on its privileges by assuming a status the Athenaeum was not supposed to have.

In general, competition between established universities was widely accepted and would frequently occur in the Dutch Republic (Clotz 1998: 125139) and elsewhere (Asche 2010). For example, poaching professors from other universities was common practice; and Leiden was no exception here. Even the Illustrious School of Middelburg had appointed the Leiden theology professor Franciscus Gomarus in 1611 without provoking hostile reactions from the university. The problem in case of the Amsterdam Athenaeum was that Leiden University considered the new school as a potential new university on its own territory, something that would eventually came true, even though the Athenaeum required 245 years to gain university status. The Athenaeum was regarded as competition as it infringed on Leiden's own privileges. It might appear odd to a modern reader that the Leiden Academic Senate even internally assessed the impact of the Amsterdam plans as "running the risk of ruin" for Leiden, ${ }^{9}$ while factually ignoring similar plans at other occasions. This shows that the economic conditions of competition were not those of a capitalist market, but of a feudal economy consisting of acquiring and defending privileges and sinecures. Leiden University would take similar actions twice more: first in 1759 when the provincial states of Zeeland deliberated founding their own university in Zierikzee (Frijhoff 1986); the second time in 1760 when the Haarlem Society of Science-the later Hollandsche Maatschappij van Wetenschappen-attempted to gain official recognition of the province Holland. While in the first case, Leiden successfully claimed an infringement of their privileges, the matter with the Haarlem Society proved to be more complicated. The Academic Senate of Leiden admitted that the Society would have a somewhat different function, as there would not be "any oral instruction and no doctors be created". Yet, examples from other countries, most notable England and France, showed "how much the fame of more than one university has been clouded and darkened, once other societies next to this have been equipped with public authority"10. The subsequent compromise tried to protect the university privileges, as the society did receive an official patent of the province Holland, but was required to publish exclusively in Dutch to maintain its distance from academic writings. 


\section{Competition Beyond Privileges}

Occasionally, universities ended up in competition beyond their own privileges. In such cases, there were limited means available to assert the claims against institutions or people from a different social status. An instructive example for this is the conflict between the University of Leiden and the Dutch mathematical practitioner Jan Jansz. Stampioen on the examination of surveyors. In 1600, Leiden had started the teaching program of Duytsche Mathematique (or Dutch Mathematics), classes in practical mathematics taught in the vernacular for a broad audience, aspiring to become military engineers or surveyors (van Winter 1988). This program was subsequently adopted by all other Dutch universities. One of the rationales for its introduction had been to improve the frequently insufficient mathematical aptitude of surveyor candidates (cf. Pouls 1997: 148). Yet, with this program the university entered into competition with very different forms of education. Apart from apprenticeships with existing surveyors these new competitors included independent schools of mathematical practitioners (Muller and Zandvliet 1987: 19-27). Since the registration as surveyor required a formal examination by the respective provincial judicial court, the universities were faced with the question how to maintain the difference in status between the students of Duytsche Mathematique and practitioners' apprentices. The Frisian University of Franeker opted for the formal pathway by allowing students to graduate in practical mathematics, surveying and geometry, issuing official promotion certificates to the candidates (Dijkstra 2012: 167-168). The Frisian Court accepted this qualification without requiring the future surveyors to take an additional exam. Unlike Franeker Leiden was not willing to put practical mathematicians formally on par with medical and judicial degrees and only offered the option of a "certificate of aptitude" ("acte van bequaemheyt"), which was not to be an official university degree. ${ }^{11}$ Thus students still had to undergo the court examination. For some time the university could maintain its prerogative, given that the official court examiners happened to be Leiden professors of mathematics (Muller and Zandvliet 1987: 137). Yet, when in 1645 Frans van Schooten the Elder died, the Hof van Holland-the judicial court of the province-appointed the aforementioned Jan Jansz. Stampioen as new examiner. In the history of mathematics, Stampioen is best known for a somewhat bizarre controversy with René Descartes about geometry in the 1630s, which also brought him in conflict with Leiden mathematicians (Costabel 1969). Stampioen ran a successful private school for mathematical practitioners briefly attended by Christiaan Huygens. Shortly after his appointment as court examiner, van Schooten's son and successor as professor of Dutch mathematics, Frans van Schooten the Younger, complained, Stampioen would "present [Leiden students] some difficult points of mathematics 
that they did not need to know" (Molhuysen 1913-1924: II, 307). Stampioen responded by suggesting that van Schooten might not teach his students well enough. In reaction van Schooten asked his university for the permission to examine the students himself. Given that the university did not want to infringe the privileges of the Hof van Holland, the curators referred van Schooten back to the court. The court, however, did not appoint van Schooten, partly not to create an affront to the appointed examiner Stampioen. More importantly, van Schooten lacked a customary qualification, because unlike his father and Stampioen he was not a registered surveyor himself (van Winter 1988: 23-25). Hence in this affair the privilege system rather hindered the university in dealing with unprivileged competition than to protect it.

\section{Using Privileges in Competition}

During the eighteenth century, universities strove to maintain their privileges. Occasionally, however, debates concerning university reforms tied privileges to forms of competition that corresponded to the modern economic model. Given the precarious economic situation of many universities and the institutional challenges the fundamental intellectual changes brought to universities and governors, adaptations had to be made. The rationale to avoid losing students to universities in foreign territories, as this would weaken the university and foster subsequent emigration of students is most explicit in the works of Christian Wolff (1725: 554-559), but also features in many decisions on university reforms (Wiesenfeldt 2002: 328-342). In such circumstances the example of other, competing universities was an option that provided academics with the opportunity to argue for the need to strengthen their discipline at their own university. Competition could be an effective argument to obtain funds for the introduction or extension of physical cabinets, chemical laboratories or botanical gardens, when rivaling universities were already in possession of those. In the cameralistic argumentation not to lose state subjects as students to foreign countries with better-equipped universities, the feudal idea of university privileges intermingled with the modern economic model of competition. ${ }^{12}$

While it may well be possible to interpret this development in terms of the emerging modern economic thinking, it is important to note that forms of competition in and among early modern universities did not follow the Luhmannian model of social orientation without social interaction. Polanyi's ideal of the market republic of science (Nye 2016) is not applicable to early modern academia. Instead, competition focused on existing systems of privileges negotiated in direct-intellectual, political, or even legal-dispute. This is not to say that the economic conditions of early modern universities did not play a 
role. They were not necessarily less present in the academic world than they are in the universities of the twentyfirst century. Yet, the economic conditions themselves were fundamentally different, requiring different responses to the challenges academics and governors found themselves in.

Still, it can be questioned whether competition necessarily needs to be related to an economic interpretation. When it comes to the competition for students between professors, different universities or other educational institutions the economic relevance seems imminent. The same applies for conflicts over direct funding and patronage. Given that the latter relates to competition between academics, different disciplines and faculties as well as other universities, the economic mode of competition-albeit not in the form of free market competition-seems ubiquitous, Yet, following the earlier argument concerning the significance of status in early modern competition (Stollberg-Rillinger 2014), the restraints for rivaling status claims in early modern society suggest that the basic principle of early modern universities' economy was rather to avoid competition than to seek it. The accepted mode of competition between academics of comparable status, that is, the academic dispute, remained an exception among the various other modes at early modern universities.

\section{Endnotes}

1 While the nature of competition is not defined in any way by rules, much economic theory has pointed out that the competition needs to be controlled by rules of fairness to be profitable for the greater good (Fehr and Schmidt 1999).

2 For a detailed analysis of the economic structure of an early modern university see Merkel (1973) and Rasche (2007), for a different example see Bauer (2008): 47-72.

3 "Aktiver Wettbewerb um den höheren sozialen Rang galt keineswegs als positive soziale Norm, sondern ganz im Gegenteil als Normverstoß, als turbatio ordinis." (StollbergRillinger 2014: 198).

4 See, for example, the role disputations played in the debate on Cartesianism in the Dutch Republic (Verbeek 1992: 13-33).

5 For a detailed discussion on lecture announcements see Rasche (2009) and Bruning (2011).

6 This literature includes Kahl (1600), Bronkhorst (1621), Zaunschliffer (1734). Bronkhorst's Tractatus brevis perspicuus et succinctus, de privilegiis studiosorum, doctorum, et professorum was reprinted at least twice in different university towns, last in Franeker in 1695. For a comprehensive discussion of the role of academic distinctions at early modern universities see Füssel (2006: 73-126).

7 University Archives Leiden, Ms. ASF462, "Acta et Decreta Facultatis Philosophicae".

8 For a discussion of the Illustrious School in Middelburg, see Frijhoff (1986), for Dordrecht see Schotel (1857), on the competition with other institutions of higher learning in the early history of Leiden University see Clotz (1998: 125-139).

9 “[W]aerdoor d'Académie binnen Leyden metter tijt groot interest soude lyden ende oock pericule van ruine loopen" Molhuysen (1913-1924: II, 159).

10 "Schoon nu de Haarlemsche Maatschappy in zoverre als daar in de weetenschappen niet mondelyk worden onderweezen, geene doctoren gecreëerd enz., van een verschillenden aard is, echter heeft de ondervindinge doen zien, hoezeer de glorie van meer dan ééne 
universiteit beneveld en verdonkerd is geworden, wanneer andere maatschappyen neffens dezelven met publyke auctoriteit wierden gemunieerd en illustre persoonen zig tot derzelver leden lieten aanneemen.” Molhuysen (1913-1924: V, 205*).

11 Dutch National Archive, The Hague, Archief van de Staten van Holland na 1572, Ms. 1369A, Stukken rakende de Universiteit te Leiden.

12 For an instructive example regarding the importance of economic thinking about universities in the transition period at the end of the eightteenth century see Gierl (2005).

\section{References}

Albrecht, Michael 1994. Eklektik. Eine Begriffsgeschichte mit Hinweisen auf die Philosophie- und Wissenschaftsgeschichte. Stuttgart: Frommann-Holzboog (=Quaestiones: Themen und Gestalten der Philosophie, 5).

Asche, Matthias 2010. Konkurrenz belebt das Geschäft, zuviel Konkurrenz schadet: Die Universitäten Rostock und Greifswald als ungleiche Schwestern. In: Hans-Uwe Lammel and Gisela Boeck (eds.). Tochter oder Schwester: Die Universität Greifswald aus Rostocker Sicht. Rostock: Universität Rostock: 7-22.

Bacon, Francis 2000. The New Organon: Edited by Lisa Jardine and Michael Silverthorne. Cambridge: Cambridge University Press.

Bauer, Jochen, Andreas Klinger, Alexander Schmidt and Georg Schmidt (eds.) 2008. Die Universität Jena in der Frühen Neuzeit. Heidelberg: Universitätsverlag Winter.

Bourdieu, Pierre 2011. The Forms of Capital. In: Imre Szeman and Timothy Kaposy (eds.). Cultural Theory: an Anthology. Chichester: Wiley-Blackwell: 81-93.

Bronkhorst, Everardus 1621. Tractatus brevis perspicuus et succinctus, de privilegiis studiosorum, doctorum, et professorum. Leiden: Mark. (later editions Harderwijk: 1652, Franeker: Strick, 1695).

Bruning, Jens 2011. Vorlesungsverzeichnisse. In: Ulrich Rasche (ed.). Quellen zur frühneuzeitlichen Universitätsgeschichte: Typen, Bestände, Forschungsperspektiven. Wiesbaden: Harrasowitz: 269-292.

Chang, Ku-Ming (Kevin) 2004. From Oral Disputation to Written Text: The Transformation of the Dissertation in Early Modern Europe. History of Universities (19): 129-187.

Chartier, Roger 1982. Espace social et imaginaire social: les intellectuels frustrés au XVIIe siècle. Annales. Economies, Sociétés, Civilisations (27): 389-400.

Clark, William 2006. Academic Charisma and the Origins of the Research University. Chicago: University of Chicago Press.

Clotz, Henrike L. 1998. Hochschule für Holland: Die Universität Leiden im Spannungsfeld zwischen Provinz, Stadt und Kirche, 1575-1619. Stuttgart: Franz Steiner.

Corcoran, Andreas 2013. The Social Metaphysics of Professors: Divine Providence, Academic Charisma and Witchcraft. In: Richard Kirvan (ed.). Scholarly Self-Fashioning and Community in the Early Modern University. Farnham: Ashgate: 121-144.

Costabel, Pierre 1969. Descartes et la racine cubique des nombres binômes. Revue d'histoire des sciences et de leurs applications (22): 97-116.

Crouch, David 2005. Tournament. London: Hambledon and London.

Descartes, René 1998. Discourse on Method: Translated by Donald A. Cress. 3. Aufl. Indianapolis: Hackett.

Dijkstra, Arjen 2012. Between Academics and Idiots: A Cultural History of Mathematics in the Dutch Province of Friesland (1600-1700). PhD thesis. Enschede: Twente University.

Dölemeyer, Barbara and Heinz Mohnhaupt (eds.) 1997. Das Privileg im europäischen Vergleich. Frankfurt am Main: Vittorio Klostermann.

Fehr, Ernst and Klaus M. Schmidt 1999. A Theory of Fairness, Competition, and Cooperation. The Quarterly Journal of Economics (114): 817-886.

Felipe, Donald Leonard 1991. The Post-Medieval ,Ars Disputandi'. PhD thesis. Austin: University of Texas. 
Felwinger, Johannes Paul 1659. Brevis commentatio de disputatione complectans totam methodum disputandi. Altdorf: Hagen.

Frijhoff, Willem 1986. Zeelands universiteit: hoe vaak het mislukte en waarom. In: Archief Mededelingen van het Koninklijk Zeeuws Genootschap der Wetenschappen: 7-41.

Frijhoff, Willem 1996a. Patterns. In: Hilde de Ridder-Symoens (ed.). A History of the University in Europe. Volume 2. Universities in Early Modern Europe (1500-1800). Cambridge: Cambridge University Press: 43-110.

Frijhoff, Willem 1996b. Graduation and Careers. In: Hilde de Ridder-Symoens (ed.). A History of the University in Europe. Volume 2. Universities in Early Modern Europe (1500-1800). Cambridge: Cambridge University Press: 355-415.

Frijhoff, Willem 1998. What Is an Early Modern University? The Conflict between Leiden and Amsterdam in 1631. In: Helga Robison-Hammerstein (ed.). European Universities in the Age of Reformation and Counter Reformation. Dublin: Four Courts Press: 149-168.

Füssel, Marian 2006. Gelehrtenkultur als symbolische Praxis: Rang, Ritual und Konflikt an der Universität der frühen Neuzeit. Darmstadt: Wissenschaftliche Buchgesellschaft.

Gierl, Martin 1997. Pietismus und Aufklärung: Theologische Polemik und die Kommunikationsreform der Wissenschaft am Ende des 17. Jahrhunderts. Göttingen: Vandenhoeck \& Ruprecht.

Gierl, Martin 2005. Die Universität als Aufklärungsfabrik. Über Kant, gelehrte Ware, Professoren als Fabrikgesellen und darüber, wer die universitätshistorisch herausragende programmatische Schrift des 18. Jahrhunderts in Wirklichkeit geschrieben hat. Historische Anthropologie (13): 367-375.

Gindhart, Marion and Ursula Kundert (eds.) 2010. Disputatio 1200-1800: Form, Funktion und Wirkung eines Leitmediums universitärer Wissenskultur. Berlin: de Gruyter.

Habermas, Jürgen 1971. Strukturwandel der Öffentlichkeit. Untersuchungen zu einer Kategorie der bürgerlichen Gesellschaft. 5. Aufl., Neuwied/Berlin: Luchterhand.

Halffmann, Willem and Hans Radder 2015. The Academic Manifesto: From an Occupied to a Public University. Minerva (53): 165-187.

Hazelkorn, Ellen 2015. Rankings and the Reshaping of Higher Education: The Battle for WorldClass Excellence. Basingstoke: Palgrave Macmillan.

Hebenstreit, Johann Christian 1717. Dissertatio logica de praeside disputationis ejusque officio. Leipzig: Zunkel.

Heereboord, Adriaan 1648. Sermo extemperaneus de recte philosophice disputandi ratione. Leiden: Hackius.

Hicks, Diana 2012. Performance-based university research funding systems. Research Policy (41): 251-261.

Hunt, Shelby D. 2000. A General Theory of Competition: Resources, Competences, Productivity, Economic Growth. Thousand Oaks: Sage Publications.

Kahl, Johannes 1600. Oratio de privilegiis et honoribus studiosorum ac professorum. Herborn: Corvinus.

Kublik, Steffen 2009. Die Universität Jena und die Wissenschaftspolitik der ernestinischen Höfe um 1800. Marburg: Tectum (= Wissenschaftliche Beiträge aus dem Tectum-Verlag/Reihe Geschichtswissenschaft, 6).

Luhmann, Niklas 1988. Die Wirtschaft der Gesellschaft. Frankfurt am Main: Suhrkamp.

Marti, Hanspeter 1999. Philosophieunterricht und philosophische Disputationen im 17. und 18. Jahrhundert. In: Rainer Schwinges (ed.). Artisten und Philosophen: Wissenschafts- und Wirkungsgeschichte einer Fakultät vom 13. bis zum 19. Jahrhundert. Basel: Schwabe: 209-232.

Marti, Hanspeter 2007. Von der Präses- zur Respondentendissertation. Die Autorschaftsfrage am Beispiel einer frühneuzeitlichen Literaturgattung. In: Rainer Christoph Schwinges (ed.). Examen, Titel, Promotionen: Akademisches und staatliches Qualifikationswesen vom 13. bis zum 21. Jahrhundert. Basel: Schwabe: 251-274.

Merkel, Gerhard 1973. Wirtschaftsgeschichte der Universität Heidelberg im 18. Jahrhundert. Stuttgart: Kohlhammer (=Veröffentlichungen der Kommission für Geschichtliche Landeskunde in Baden-Württemberg, 73).

Merton, Robert K. 1957. Priorities in Scientific Discovery: A Chapter in the Sociology of Science. American Sociological Review (22): 635-659.

van Miert, Dirk 2009. Humanism in an Age of Science: The Amsterdam Athenaeum in the Golden Age, 1632-1704. Leiden: Brill (=Brill Studies in Intellectual History, 179). 
Moeller, Bernd 2011. Zwinglis Disputationen: Studien zur Kirchengründung in den Städten der frühen Reformation. Göttingen: Vandenhoeck \& Ruprecht.

Molhuysen, Philip C. 1913-1924. Bronnen tot de geschiedenis der Leidsche universiteit 1574-1811. 7 vols. Den Haag: Martinus Nijhoff.

Moraw, Peter 1982. Aspekte und Dimensionen älterer deutscher Universitätsgeschichte. In: Peter Moraw and Volker Press (eds.). Academia Gissensis. Beiträge zur älteren Gießener Universitätsgeschichte. Marburg: Elwert: 1-43.

Muller, E. and Kees Zandvliet (eds.) 1987. Admissies als landmeter in Nederland voor 1811. Alphen: Canaletto.

Nadolny, Andrew and Suzanne Ryan 2015. McUniversities Revisited: A Comparison of University and McDonald's casual Employee Experiences in Australia. Studies in Higher Education (40): 142-157.

Nye, Mary Jo 2016. The Republic versus the Collective: Collaboration and Competition in Modern Science. NTM (24), this issue.

Pouls, Henri C. 1997. De Landmeter: Inleideing in de geschiedenisv an de Nederlandse Landmeetkunde van de Romeinse tot de Franse tijd. Alphen: Canaletto.

Prückner, Andreas 1656. Libellus De Artificio Disputandi. Erfurt: Birckner.

Rasche, Ulrich 2007. Die deutschen Universitäten zwischen Beharrung und Reform. Über inneruniversitäre Berechtigungssysteme und herrschaftliche Finanzstrategien des 16. bis 19 . Jahrhunderts. Jahrbuch für Universitätsgeschichte (10): 13-33.

Rasche, Ulrich 2009. Seit wann und warum gibt es Vorlesungsverzeichnisse an den deutschen Universitäten? Zeitschrift für Historische Forschung (36): 445-478.

Saada, Anne 2008. Die Universität Göttingen: Tradition und Innovation gelehrter Praktiken. In: Hans Erich Bödeker, Philippe Büttgen and Michel Espagne (eds.). Die Wissenschaft vom Menschen in Göttingen um 1800: Wissenschaftliche Praktiken, institutionelle Geographie, europäische Netzwerke. Göttingen: Vandenhoeck \& Ruprecht: 23-46.

Schotel, Gilles D.J. 1857. De illustre school te Dordrecht: Eene bijdrage tot de geschiedenis van het schoolwezen in ons vaderland. Utrecht: Kemink.

Simmel, Georg 1955. Conflict. In: Conflict. The Web of Group-Affiliations. Glencoe, Illinois: The Free Press: 11-123.

Stichweh, Rudolf 1991. Der frühmoderne Staat und die europäische Universität. Frankfurt am Main: Suhrkamp.

Stollberg-Rillinger, Barbara 2011. Rating-Ranking-Rangkonflikte. Was macht akademische Exzellenz aus? In: Helwig Schmidt-Glintzer (ed.). Die Reformuniversität Helmstedt 15761810. Vorträge zur Ausstellung "Das Athen der Welfen". Wiesbaden: Harrassowitz: 9-23.

Stollberg-Rillinger, Barbara 2014. Logik und Semantik des Ranges in der Frühen Neuzeit. In: Ralph Jessen (ed.). Konkurrenz in der Geschichte: Praktiken - Werte - Insitutionalisierungen. Frankfurt: Campus: 196-227.

Thomasius, Jacob 1670. Erotemata logica pro incipientibus: accessit pro adultis processus disputandi. Leipzig: Frommann.

Vandermeersch, Peter A. 1996. Teachers. In: Hilde de Ridder-Symoens (ed.). A History of the University in Europe. Volume 2. Universities in Early Modern Europe (1500-1800). Cambridge: Cambridge University Press: 210-255.

Verbeek, Theo 1992. Descartes and the Dutch: Early Reactions to Cartesian Philosophy, 16371650. Carbondale \& Edwardsville: Southern Illinois University Press.

Vermij, Rienk 1991. Promoveren te Utrecht aan het eind van de zeventiende eeuw. Maandblad Oud-Utrecht (64): 33-38.

Wiesenfeldt, Gerhard 2002. Leerer Raum in Minervas Haus. Experimentelle Naturlehre an der Universität Leiden 1675-1715. Amsterdam: Edita KNAW.

Wiesenfeldt, Gerhard forthcoming. Academic Writings and the Rituals of Early Modern Universities. Intellectual History Review.

van Winter, Pieter J. 1988. Hoger beroepsonderwijs avant-la-lettre. Bemoeiingen met de vorming van landmeters en ingenieurs bij de Nederlandse universiteiten van de 17e en 18e eeuw. Amsterdam: Noord-Holland. 
DifFERENT MOdes of COMPETITION?

Wolff, Christian 1725. Vernünfftige Gedancken von dem Gesellschafftichen Leben der Menschen und insonderheit dem gemeinen Wesen zu Beförderung der Glückseeligkeit des menschlichen Geschlechtes. Halle: Renger.

Zaunschliffer, Otto Phillipp 1734. Tractatio juridica de privilegiis professorum. Halle: Hendelius.

\section{Gerhard Wiesenfeldt}

School of Historical and Philosophical Studies

The University of Melbourne

Melbourne

VIC 3010

Australia

E-Mail: gerhardw@unimelb.edu.au 